\title{
Establishing Programme-Target Approach-Based Institutional Entrepreneurship Environment in Krasnodar Krai
}

\author{
Elena Vladislavovna Korolyuk \\ Ekaterina Viktorovna Mezentseva
}

Kuban state university, Russian Federation, Krasnodar ; Email: sci.publ@gmail.com

\section{Doi:10.5901/mjss.2015.v6n6s4p583}

\begin{abstract}
The key factors influencing the formation of institutional business environment with relation to the programme-target approach have been examined in the article. Various scientific views on the programme-target management, federal target and regional programs as the most essential tools of social and economic development management of the region (Krasnodar Krai) have been considered. Within the framework of the programme-target approach measures promoting favourable institutional business environment and further social-economic development of the region have been emphasized.
\end{abstract}

Keywords: entrepreneurship, institutional environment, programme-target management.

\section{Introduction}

Establishing favorable institutional entrepreneurship environment in current conditions is one of the main objectives of the government's policy to be implemented using the tools of programme-target regulation, improvements of the institutional functional business structures (Kuztetsova, 2010, Molchan, 2011, Korolyuk, 2011)

Programme-target management is still one of the most effective entrepreneurship development regulation methods, especially those relating small and medium-scale business, since this type of management is one of the most accessible and clear tools facilitating to centralize resources for achieving specific socially significant goals. The creation of such an approach is based on the provision of the law On State Forecasting and Programmes of Social and Economic Development of the Russian Federation (The RF Federal Law of July 20, 1995 r. No. 115).

In the science of management, the conception of programme-target management is interpreted from different perspectives. B.A. Raizberg defines the program-targeted management broadly and narrowly (Raizberg, 2012). In a broad sense, programme-target management is the management of the subject's impact on the management object, which is generated on the basis of the system analysis methodology. The means to attain management goals are selected according to those goals and the scope of all stages of life cycle. The essence of the programme-target management in the narrow sense is defined by those scholars only as a development and implementation of various target complex programmes.

V.A. Makeev while solving entrepreneurship development problems using programme-target management proposes to take into account a problem-programme tenor (Makeev V.A., Galaburda V.G, 2002).

\section{Research Methods}

The problem approach provides an opportunity in the broad economic sense to consider the strategic trends in economy development being focused on the core tasks for achieving the long-term social and economic objectives.

The above mentioned scientist links the problem-programme approach to strategic planning. It is the strategic plans that have not only long-range but also a problematic specificity. Therefore, laying the emphasis on the major problems is seen to be possible only within the conception of the strategic plan. Strategic planning is the process of creating and maintaining the strategic coordination between the goals of the organisation and its real chances to be successful in selling products and services. Strategic planning rests on the policy statement of the mission of the organisation's strategic goal, representation of the specific goals and objectives, on the volume of production, resources and growth strategy (Makeev V.A., Galaburda V.G, 2002).

The problem-programme approach relating entrepreneurship based on a number of fundamental provisions of 
strategic planning:

- $\quad$ specifying priority ways of entrepreneurship development and its environment;

- attaining the final result according to the objective set;

- national economic efficiency;

- comprehensive reasoning of the managerial decision and its resource provision.

At the same time, this approach, in our view, is instrumental for solving the following business development management problems:

- aiming at the final social and economic goals of development;

- well-balanced and optimal alignment of goals, resources and business activities;

- relevance of the alternative ways of attaining the goals of the programme;

- precise statement of the goals and objectives of the federal, regional and municipal levels of management;

- decomposition of the main goal on specific goals, objectives and business activities.

Establishing the institutional business environment using the problem-programme approach consists of several steps shown on the chart (Figure 1).

\begin{tabular}{|c|}
\hline $\begin{array}{c}\text { Specifying the municipal or regional problems arising when the institutional } \\
\text { business environment is being formed }\end{array}$ \\
\hline Stating goals for solving the problems revealed \\
\hline Stating the actirities required \\
\hline Resources allocation for the activities \\
\hline Effective allocated res ources spending \\
\hline
\end{tabular}

Figure 1. Problem-programme approach for institutional entrepreneurship environment formation.

At the first stage, the main municipal or regional problem is specified and the possibility of its solving using the programme method is proved.

At the second stage, stating some of the goals within the general problem and the set of logical interrelated tasks to achieve the goal within the program is done.

At the third stage, the measures (organisational, social, scientific, environmental, etc.) are found, discussion, adjustment and approval of the conception of the programme, its main elements for effective implementation of the programme objectives take place.

The fourth stage is essential to perform segmentation of the measures depending on the tasks being tackled, to allocate the necessary resources irrespective of their being branch or regional for the implementation of measures.

The fifth stage involves evaluation of the program activities efficiency considering the degree of business environment development of the region where the activities are to take place, as well as control measures.

Ye.N. Belkina in her scientific papers noted that entrepreneurship could only be developed if there were certain internal and external conditions in the country for the development of the business environment established (Belkina, 2013). Programme activities, according to the scientist's opinion should include both measures for the development of business itself and improvement of the parameters of the business environment. A characteristic feature of this approach is differentiation of measures according to the degree of territorial development of the business environment being regulated. This approach has considerable advantages compared with the above examined ones as it makes it possible to achieve precise targeting of the ongoing programme activities.

In this context, the priority trends in institutional environment development have been formulated as programme activities divided into two packages. A general package of program activities includes measures aimed at the overall development of business itself and activities focused on the development of the business environment. This activities package is implemented in the territory of all administrative units of the region and it is financed from the regional budget and controlled by the regional authorities.

A variative package of the program activities also includes the measures aimed at developing business itself and improving the parameters of the institutional environment. A characteristic feature of this package is differentiation of measures according to the degree of the territorial development of the institutional environment regulated. 

follows:

The expected results from the activities package introduction and implementation, according to the author, are as

- target, adaptive and selective regulation of institutional environment development parameters in the region considering its territorial inhomogeneity according to the attributive parameters;

- elimination of the disequilibrium in the system of regional support to business which is extremely centralized and enunciative;

- $\quad$ finding regions with critically low development of the institutional environment to take anti-crisis measures for business development;

- improvement of the favourable institutional environment due to the coordination of regional and local authorities' activities supported by the coordination structures being the part of the institutional provision (Lopatin, 2014).

However, along with the transformation processes significant difficulties arise. According to Ye.V. Korolyuk, one of these difficulties is the formation of powerful institutional barriers causing low efficiency of business activities (Korolyuk, 2012). At the same time, the process of establishing a favourable institutional environment is full of contradictions and the quality of the economic system being established depends on the effective solving of those contradictions (Korolyuk, 2014).

\section{The Research Body}

In the conditions of the economy being transformed, it is particularly important to examine the development potential of the favourable institutional environment of entrepreneurship at the regional level. This development can be accomplished through performance evaluation of the federal, regional and municipal target programmes. The levels of programmetarget management and the areas of activity are given in Table 1.

Table 1. Levels of programme-target management

\begin{tabular}{|l|l|}
\hline Levels & Contents \\
\hline Federal & $\begin{array}{l}\text { Stating the general principles of the organisation and formation of the programme-target method of business } \\
\text { management on Russia's territory. Rendering support for the regions to implement the programme-target method of } \\
\text { management. Legal regulation of the regional and local problems relating to using the programme-target method of } \\
\text { management in the Russian regions. }\end{array}$ \\
\hline Regional & $\begin{array}{l}\text { Creating conditions to implement the target programmes at the regional and municipal levels. To render support to } \\
\text { the municipalities for their implementation of the programme-target method of management. Regular reporting on } \\
\text { the implementation of the management programme to the senior federal authority. }\end{array}$ \\
\hline Municipal & $\begin{array}{l}\text { Carrying out programme-target management in the municipalities. Regular reporting on the implementation of the } \\
\text { management programme to the senior regional authority. }\end{array}$ \\
\hline
\end{tabular}

The advantage of using the programme-target management at the regional and municipal level is that there is an immediate focus on the existent business needs of the particular region or the municipality (Mezentseva, 2009).

There is no doubt that taking into account the main interests of the business entities becomes an imperative for the development of the target management function.

On the assumption of the above said, the main effects of the programme-target management of the institutional environment development of entrepreneurship at the sub-national level are:

- the economic effect connected with the resource base expansion of the of the institutional environment development (based on subsidiary state's funding, and the multiplier's activities to attract private investments), enhancing its efficiency and as a result development of businesses entities in the region;

- the social effect, manifesting itself in the balance in the quality of life of both entrepreneurs and local population of the region, development and implementation of the general goals;

- the organizational effect reflecting the processes of favorable business climate creating by establishing relationships of business, government entities and the society;

- the political effect linked with strengthening of the institute of local government as the foundation of a civil society through the discussion and coordination of the mechanisms of joint private and public formation of the institutional environment.

The form of the direct state involvement in the development of entrepreneurship on the programme-target basis is the federal and regional programmes as well as the programmes implemented at the municipal level. For example, in 
Krasnodar Krai they implement the federal programmes that promote the development of youth business (the brief description of programmes "Start", "Development", "UMNIK" is given in Table 2), the program of the Russian Federation Economic Development and Innovative Economy" (Order of the Government of the Russian Federation of August 13, 2013 No. 1414-p); sub-programme of Krasnodar Krai State Support for Small and Medium-scale enterprises in Krasnodar Region for 2014 - 2018, state program Economic Development and Innovative Economy; municipal programmes to support small-scale businesses in the rural areas (Table 3).

The primary support in Krasnodar Krai is provided for small and medium-scale enterprises working in such areas as:

- energy saving technologies and renewable power generation;

- medical equipment and materials, biotechnologies, new drugs;

- IT-services, telecommunication and navigation technologies;

- new building materials, structures and technologies;

- new technologies used in the sphere of full and minor of the housing stock and maintaining $и$ housing and utilities infrastructure and amenities;

- environment preservation, including recycling of production and consumption wastes, introducing recyclable materials production technologies, water treatment and water consumption;

- electronics, precision engineering, instrument engineering;

- nanotechnologies and nanomaterials;

- novel industrial technologies, materials, equipment.

Table 2. Youth business support programmes in Krasnodar Krai

\begin{tabular}{|l|l|l|}
\hline Statutory regulation / Institutor & Type of Support & Outcome \\
\hline $\begin{array}{l}\text { Development Programme / Small Innovative } \\
\text { Enterprises in Science and Technology } \\
\text { Foundation }\end{array}$ & $\begin{array}{l}\text { Aid grants within Development } \\
\text { Programme }\end{array}$ & $\begin{array}{l}\text { Up to } 50 \% \text { of actual expenses, but no more } \\
\text { than } 15 \mathrm{~m} \text { rubles }\end{array}$ \\
\hline $\begin{array}{l}\text { Start Programme / Small Innovative } \\
\text { Enterprises in Science and Technology } \\
\text { Foundation }\end{array}$ & Aid grants within Start Programme & $\begin{array}{l}\text { Up to } 6 \mathrm{~m} \text { rubles within } 3 \text { years: up to } 1.0 \mathrm{~m} \\
\text { rubles during the first year, up to 2.0 m } \\
\text { rubles during the second year and up to } 3.0 \\
\mathrm{~m} \text { rubles during the third year of the project }\end{array}$ \\
\hline $\begin{array}{l}\text { UMNIK Programme / Small Innovative } \\
\text { Enterprises in Science and Technology } \\
\text { Foundation }\end{array}$ & $\begin{array}{l}\text { Aid grants within Participant to the } \\
\text { UMNIK Youth Science and Innovation } \\
\text { Competition Programme }\end{array}$ & 200,000 thousand rubles per year \\
\hline $\begin{array}{l}\text { Development of cooperation of the Russian } \\
\text { universities and institutions implementing } \\
\text { integrated projects for high-tech production / } \\
\text { Ministry of Education and Science }\end{array}$ & $\begin{array}{l}\text { Aid grants for implementation of the } \\
\text { integrated complex projects aimed at } \\
\text { high-tech production, paid jointly with } \\
\text { the Russian universities }\end{array}$ & $\begin{array}{l}\text { Up to } 50 \% \text { of the expenses, but not more } \\
\text { than 100,000 rubles per year, not longer } \\
\text { than three years }\end{array}$ \\
\hline
\end{tabular}

Currently, youth business of Krasnodar Krai covers over $26 \%$ of tax revenues and $40 \%$ employment, that proves cost effectiveness of youth entrepreneurship support.

Table 3. Type of support to entrepreneurship institutional environment in Krasnodar Krai

\begin{tabular}{|c|c|c|}
\hline Statutory regulation / Institutor & Type of Support & Outcome \\
\hline \multicolumn{3}{|l|}{ Direct financial support } \\
\hline \multirow{5}{*}{$\begin{array}{l}\text { State support for small and medium-scale } \\
\text { businesses for 2014-2018 / } \\
\text { Investment and Project Support } \\
\text { Department }\end{array}$} & $\begin{array}{l}\text { Subsidising a share of electrical grid facilities } \\
\text { connection costs }\end{array}$ & $\begin{array}{l}\text { Up to } 70 \% \text { of production costs but no more than } 160,000 \\
\text { rubles }\end{array}$ \\
\hline & $\begin{array}{l}\text { Subsidising a share of the indemnification } \\
\text { fund fee paid when joining a self-regulatory } \\
\text { organisation }\end{array}$ & $\begin{array}{l}\text { Up to } 70 \% \text { of production costs but no more than } 210,000 \\
\text { rubles }\end{array}$ \\
\hline & $\begin{array}{l}\text { Subsidising a share of the costs at the early } \\
\text { stage of activity as regards purchase of fixed } \\
\text { and intangible assets. }\end{array}$ & $\begin{array}{l}\text { Up to } 70 \% \text { of production costs, but no more than } 300,000 \\
\text { rubles }\end{array}$ \\
\hline & $\begin{array}{l}\text { It is subsidising a share of the loan interest } \\
\text { costs }\end{array}$ & $\begin{array}{l}\text { Up to } 2 / 3 \text { of production costs, but not more than } 2 / 3 \text { of the } \\
\text { refinancing rate of the Russian Federation }\end{array}$ \\
\hline & $\begin{array}{l}\text { Subsidising a share of the lease payment } \\
\text { costs }\end{array}$ & $\begin{array}{l}\text { Up to } 2 / 3 \text { of production costs, but not more than } 2 / 3 \text { of the RF } \\
\text { refinancing rate for the residual cost of the leasing item and } \\
\text { for the accounting period, divide for the number of days in a } \\
\text { year and multiplied by } 100 \%\end{array}$ \\
\hline
\end{tabular}




\begin{tabular}{|l|l|l|}
\hline Statutory regulation / Institutor & Type of Support & Outcome \\
\hline \multicolumn{2}{|l|}{ Indirect: infrastructure } & Business Incubator of Kuban State University \\
\hline $\begin{array}{l}\text { Business Incubator of Kuban State } \\
\text { University }\end{array}$ & Reduced rent of office premises, consulting support \\
\hline $\begin{array}{l}\text { Armavir Business Incubator of North- } \\
\text { Caucasian Institute of Business, } \\
\text { Engineering and Information Technologies }\end{array}$ & $\begin{array}{l}\text { Armavir Business Incubator of North- } \\
\text { Caucasian Institute of Business, Engineering } \\
\text { and Information Technologies }\end{array}$ & $\begin{array}{l}\text { Reduced rent of office premises, information and consulting } \\
\text { support }\end{array}$ \\
\hline $\begin{array}{l}\text { Development Kropotkin Business } \\
\text { Incubator }\end{array}$ & Development Kropotkin Business Incubator & $\begin{array}{l}\text { Reduced rent of office premises, information and consulting } \\
\text { support }\end{array}$ \\
\hline
\end{tabular}

Small and medium-scale enterprises of Krasnodar Krai are actively developing. In 2014, 275.4 thousand small and medium-sized enterprises did business in Krasnodar Krai, most of them worked in sales and repair, real estate transactions, rent and services sectors, as well as transport and communications. Over 621,500 of Krasnodar Krai population are employed by small and medium-sized businesses, most of them working in the sphere of sales and repair, in production and construction sectors. The turnover in these spheres of economy amounted over one trillion rubles, mainly in sales and repair, in production and construction sectors (Table 4) [12].

Table 4. Key indicators of small and medium-scale enterprises in Krasnodar Krai

\begin{tabular}{|l|c|c|c|}
\hline Indicator & 2012 & 2013 & 2014 \\
\hline The number of small and medium-scale business entities & 295,373 & 271,839 & 275,458 \\
\hline The average number of employees of small and medium-scale businesses, people & 610,647 & 618,440 & 621,474 \\
\hline The turnover of small and medium-scale enterprises, m rubles & $1,377470,5$ & $1,512455,0$ & $1,620418,4$ \\
\hline
\end{tabular}

At the same time, there are some unresolved problems in the field of small and medium-scale business and its environment in Krasnodar Krai:

- small and medium-scale business is still developed heterogeneously;

- lack of credit financing for small and medium-scale businesses entering the sphere of economy;

- lack of funds for small and medium-scale business development in the local budgets, inefficient and discriminate allocation of financial resources;

- inaccessible general and specialist consultation service for small and medium-scale businesses;

- low demand for small and medium-scale businesses products, especially for agricultural products;

- lack of highly-qualified personnel employed in small and medium-scale businesses.

These problems are complex and they can be solved only over mid-time period. Solving problems of small and medium-scale business development in Krasnodar Krai using the program-target method will facilitate funding, consistency, timeliness and completeness of decision making, thereby ensuring funds effectiveness and the desired outcome.

A particular emphasis in the subprogramme State Support for Small and Medium-scale Enterprises in Krasnodar Region for 2014 - 2018 of the State programme of Krasnodar Krai Economic Development and Innovative Economy" (subprogramme) is made on the financial support of the region's entrepreneurship. This support includes reimbursement of expenses incurred by the entrepreneurs when effecting their lease payments and the initial leasing contract installment. The subprogramme contains 13 main activities in the following areas: development of the financial support system for small and medium-sized enterprises; granting support to the municipal programmes of small and mediumsized enterprises development; information, legal, consulting service and training personnel for small and medium-sized businesses. The main task is to increase the share of small and medium-scale businesses in the total turnover of the business entities of Krasnodar Krai [13].

The total funding allocation of the subprogramme using the funds of the regional budget is $900,883.1$ thousand rubles, including: 2014 - 144,061.8 thousand rubles; 2015 - 153,606.3 thousand rubles; 2016 - 189,055.0 thousand rubles; 2017 - 202,205.0 thousand rubles; 2018 - 211,955.0 thousand rubles.

The program-target method used for implementation of this programme will ensure the unity of the clearly structured and formulated content of the program with the financial and organisational mechanisms for programme implementation, as well as the control over the intermediate and final results of the programme implementation of the (Order of the Ministry for Strategic Development Investments and Foreign Economic Activity of Krasnodar Krai of September 23, 2014. No. 168). 


\section{Conclusions}

The programme-target method of solving problems is an important tool for improving the efficiency of the work at all stages; the method facilitates the process of sequential workflow with the results being assessed. The use of the program-target method is aimed at creating conditions for effective resources management, combining the integrated approach with the sound funds expenditure. The main advantages of programme-target method in solving the above said problems are:

1) the integrated approach for solving problems. Goals, objectives and main focus areas of the Programme cover a significant number of factors influencing its effectiveness and this will help to see the priority objectives depending on the funds;

2) distribution of authority and responsibilities. Within the subprogramme, a clear division of authority and responsibility is made, which in general enhances efficiency of the program activities;

3) coordination in problem solving. The Coordinator of the Subprogramme is appointed to solve the arising problems effectively;

4) a guarantee of full and well-timed funding. The mechanism and scope of finance for program activities is stated in the Sub-program for full and well-timed payment of the activities performed;

5) marking out the evaluation criteria and socio-economic impacts of the solution to the problem. Practicability and benefit of the programme-target method is induced by necessity to achieve the most optimal qualitative and quantitative results in the course of the programme implementation while maintaining efficiency in selecting the ways of solving problems.

The current state of the institutional business environment is characterized by a multitude of problems and obstacles which cannot be eliminated without the government's interference. For this purpose, it is necessary to change the existing paradigms relating business support and to make the business environment the point of address of the state's impact rather than business entities.

Taking into consideration the statistical indicators of entrepreneurship and strategic goals of the programmes being implemented, it is quite obvious that the state support is allocated on the businesses' financial problems and environment is not addressed enough (Mezentseva, 2008). From our point of view, the programme-target approach should include measures to develop a favorable institutional environment of entrepreneurship. These activities include the following:

- $\quad$ updating the juridical base for doing business;

- establishing an entrepreneurship economic security system;

- development of business environment infrastructure facilities including finance and credit support (business incubators, technology parks, foundations, employment agencies), export support and public organisations;

- information and consulting support;

- development of civil-legal institution of patronage with account of the latest positive legislation updating;

- development of public-private partnership.

To sum up, it should be noted that in the new conditions of modernisation and development of innovative economy, the programme-target approach should be the effective tool for establishing a favorable institutional environment of entrepreneurship and further social and economic development of the region.

\section{References}

Belkina Ye.N. Analysis of the Internal and External Environment as a Basis for Taking Strategic Solutions: collection of research papers // Agricultural Science, Creativity, Growth. - 2013. - P. 287-290.

Korolyuk Ye.V. Specific Characteristics of Institutional and Economic System Formation in Present-day Russia // Voprosy Economiki I Prava. - 2012. - No. 51. - P. 54-60.

Korolyuk Ye.V. Use of Dialectic Method in Economic Studies // World Applied Sciences Journal. 2014. T. 30. No. 6. P. 747-750.

Korolyuk Ye.V. A Change in Character of Rent Strategic Orientation in the Development of the Russian Economy // International Scientific Researches. 2011. No 1-2. P. 61-62.

Kuztetsova O.B. The Institutional Environment of the Russian Small-scale Business. Ph.D. thesis in Economics. Tomsk, 2010.

Lopatin A.V. Programme and Target management of the Region's Business environment // A Regional Pattern of Development: Economic and Marketing Determinants: collection of research papers of the 7th All-Russia Scientific Conference. - Stavropol: AGRUS of Stavropol State Agrarian University, 2014. - P. 98 - 102.

Makeev V.A., Galaburda V.G. Methodology of Economic Problems Solving of the Regional Transportation Systems // Transportation Information Bulletin. - 2002. - No. 9. - P. 23.

Mezentseva Ye.V. Business Issues of Entrepreneurship Development in the Youth Environment: Monograph // Ye.N. Belkina, Ye.V. 
Mezentseva. - Stavropol: ServiceShkola, 2009.

Mezentseva Ye.V. Analysis of Present-day Entrepreneurship Development in Krasnodar Krai // Bulletin of Belgorod University of Cooperation, Economics and Law. - 2008. - No. 3. - P.223-226.

Molchan A.S. Reproduction and Capitalization of the Economic Potential of the Regional Social and Economic Systems: Monograph. Krasnodar, 2011.

Order of the Ministry for Strategic Development Investments and Foreign Economic Activity of Krasnodar Krai of September 23, 2014. No. 168 On Approval of support recipient's questionnaire form to implement the Sub-programme Government Support to Small and Middle-scale Entrepreneurship in Krasnodar Krai for 2014 - 2018 of Krasnodar Krai's Government Programme Economic Development and Innovation Economy // Information and Legal System GARANT.

Raizberg B.A. Target Programmes in the System of Economy Government Control - M.: Laroratoriya Knigi, 2012. - 332 p.

Small and Middle-scale Entrepreneurship of Krasnodar Region: [Electronic Resource] URL: http://www.mbkuban.ru/pages/ ekonomicheskie-pokazateli.html (accessed date - 13.07.2015).

The RF Federal Law of July 20, 1995 r. No. 115-\$3 On State Forecasting and Social and Economic Development Programmes of the Russian Federation // Information and Legal System ConsultantPlus. 